Kalamatika: Jurnal Pendidikan Matematika

\title{
ERRORS ANALYSIS OF STUDENTS IN SOLVING VOLUME OF THE SOLID OF REVOLUTION PROBLEM IN TERM OF CRITICAL THINKING ASPECTS
}

\author{
Betty Kusumaningrum ${ }^{1}$, Muhammad Irfan $^{2}$, Zainnur Wijayanto ${ }^{3}$ \\ ${ }^{1}$ Universitas Sarjanawiyata Tamansiswa, Jl. Batikan UH III, Umbulharjo, Yogyakarta, Indonesia \\ betty.kusumaningrum@ustjogja.ac.id \\ ${ }^{2}$ Universitas Sarjanawiyata Tamansiswa, Jl. Batikan UH III, Umbulharjo, Yogyakarta, Indonesia \\ muhammad.irfan@ustjogja.ac.id \\ ${ }^{3}$ Universitas Sarjanawiyata Tamansiswa, Jl. Batikan UH III, Umbulharjo, Yogyakarta, Indonesia \\ zainnurw@ustjogja.ac.id
}

\section{ABSTRACT}

Students of mathematics education need to have a good understanding in solving integral calculus problems, but often have difficulty in understanding the subject material. The difficulties can be seen from the mistakes made by students when solving the problems. This article aims to analyze the errors of students in learning integral calculus especially in the subject of volume of the solid of revolution in terms of critical thinking aspects. This research is a qualitative descriptive study involving twenty-four of $6^{\text {th }}$-semester students of mathematics education at a private university in Yogyakarta. The research subjects were chosen purposively by considering: student errors in determining the volume of the solid of revolutions with integral techniques in terms of critical thinking aspect. The findings of this study indicate, student errors in determining the function of integrals, write down the rules of integral writing, misunderstanding in algebraic concepts, adding constants $C$, write down limits and sigma notations, determine integration methods, determine boundaries integration, writing $\Delta x$ in integral sign, and error in determining the radius of the solid of revolution.

\section{ARTICLE INFORMATION}

\begin{tabular}{l} 
Keywords \\
\hline Critical thinking \\
Error analysis \\
Problem-solving \\
The volume of the solid of revolution
\end{tabular}

Article History

Submitted Mei 4, 2020

Revised Aug 21, 2020

Accepted Aug 21, 2020

\section{Corresponding Author}

Betty Kusumaningrum

Universitas Sarjanawiyata Tamansiswa

Jl. Batikan UH III, Tahunan, Umbulharjo, Yogyakarta, Indonesia

Email: betty.kusumaningrum@ustjogja.ac.id

\section{How to Cite}

Kusumaningrum, B., Irfan, M., \& Wijayanto, Z. (2020). Errors Analysis of Students in Solving Volume of the Solid of Revolution Problem in Term of Critical Thinking Aspects. Kalamatika: Jurnal Pendidikan Matematika, 5(2), 119-132.

https://doi.org/10.22236/KALAMATIKA.vol5no2.2020pp119-132

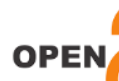




\section{INTRODUCTION}

Mathematics education students need a good understanding of solving mathematical problems, but often have difficulty in understanding the subject material. The difficulties can be seen from the mistakes made by students when solving the problems. A problem occurs when a student wants to achieve goals state but has no obvious method (Mayer \& Wittrock, 1996). Problems can occur because there is a discrepancy between the situation and the objectives to be achieved (Irfan, 2017; Widodo, 2013). The problem can be interpreted as an unknown entity and the solution needs to be found (Anggo, 2011). In mathematics, problems are usually presented in the form of mathematics problems (Widjajanti, 2009; Widodo, Purnami, \& Prahmana, 2017). But not all mathematical problems are a problem for students. A mathematical problem becomes a problem for students if they want to solve the problem, but have no idea to solve it (Widodo \& Sujadi, 2015). If students immediately know how to solve it correctly, it cannot be a problem for them (Widodo \& Turmudi, 2017).

Not only students but also everyone must be having problems because problems and problem-solving are part of the process of maturity that must be passed by everyone (Anggo, 2011). Problem-solving required students to apply and to integrate many mathematical concepts as well as making a decision (Tambychik \& Meerah, 2010). Therefore, problem-solving in mathematics education is important to be instilled in students so they can be accustomed to solving problems well, both problems in mathematics, in other fields of study, or in more complex daily life (Effendi, 2012; Pardimin \& Widodo, 2016; Widodo, Turmudi, Dahlan, Istiqomah, \& Saputro, 2018). Problem-solving is a high intellectual activity because students are required to use their knowledge and skills to solve unusual problems (Arigiyati \& Istiqomah, 2016). The ability to solve mathematical problems is the ability to overcome the problems that were not clear to answer (Widodo, Darhim, \& Ikhwanudin, 2018). Mathematical problem solving can be used as a means of sharpening careful, logical, and critical reasoning (Widjajanti, 2009). By thinking critically, people can easily make rational decisions (Haryani, 2011).

The ability to think critically of each person varies depending on the intensity of those people in developing critical thinking skills. This ability becomes important to be accustomed by everyone because if there is a problem they can provide solutions to solve the problems with rational and carefulness (Amir, 2015). So, critical thinking is a process that aims to make some decisions as a form of problem's solution with full consideration. The ability to think critically 
can be seen from the indicators of critical thinking. There are five indicators of critical thinking ability, namely: (1) Analyzing, is the ability to decompose a structure into components, (2) Synthesize, is the ability to combine parts into new arrangements, (3) Solve problems, is the ability to apply concepts, (4) conclude, is the ability to obtain new understanding, and (5) evaluating, is the ability to judge based on certain criteria (Santoso, 2009). Researchers use those indicators to identify student errors in solving integral calculus problems. Indicators of critical thinking are presented in Table 1.

Table 1. Indicators of Critical Thinking

\begin{tabular}{ll}
$\begin{array}{l}\text { Indicators of Critical Thinking } \\
\text { (Santoso, 2009) }\end{array}$ & $\begin{array}{c}\text { Indicators of Critical Thinking That Used to Identify Student Errors in } \\
\text { Solving Integral Calculus Problems }\end{array}$ \\
\hline Analyzing & Identify the characteristics of the concept \\
Synthesize & Compare another concept \\
Solve problems & Identify the concept that used in making a decision \\
Conclude & Provide an assessment/explanation of the concept \\
Evaluating & Evaluate the decisions that have been taken \\
\hline
\end{tabular}

Subject material in Mathematics Education Study Programs mostly requires critical thinking skills, one of them is Integral Calculus. Integral calculus is a course that must be taken by all mathematics education students and needs to be mastered broadly and deeply. However, there are still many students who have difficulty in understanding the subject material, especially in the volume of the solid of revolution. Midterm Examination scores for $6^{\text {th }}$-semester students on the problem of the volume of the solid of revolution can be seen in Figure 1.

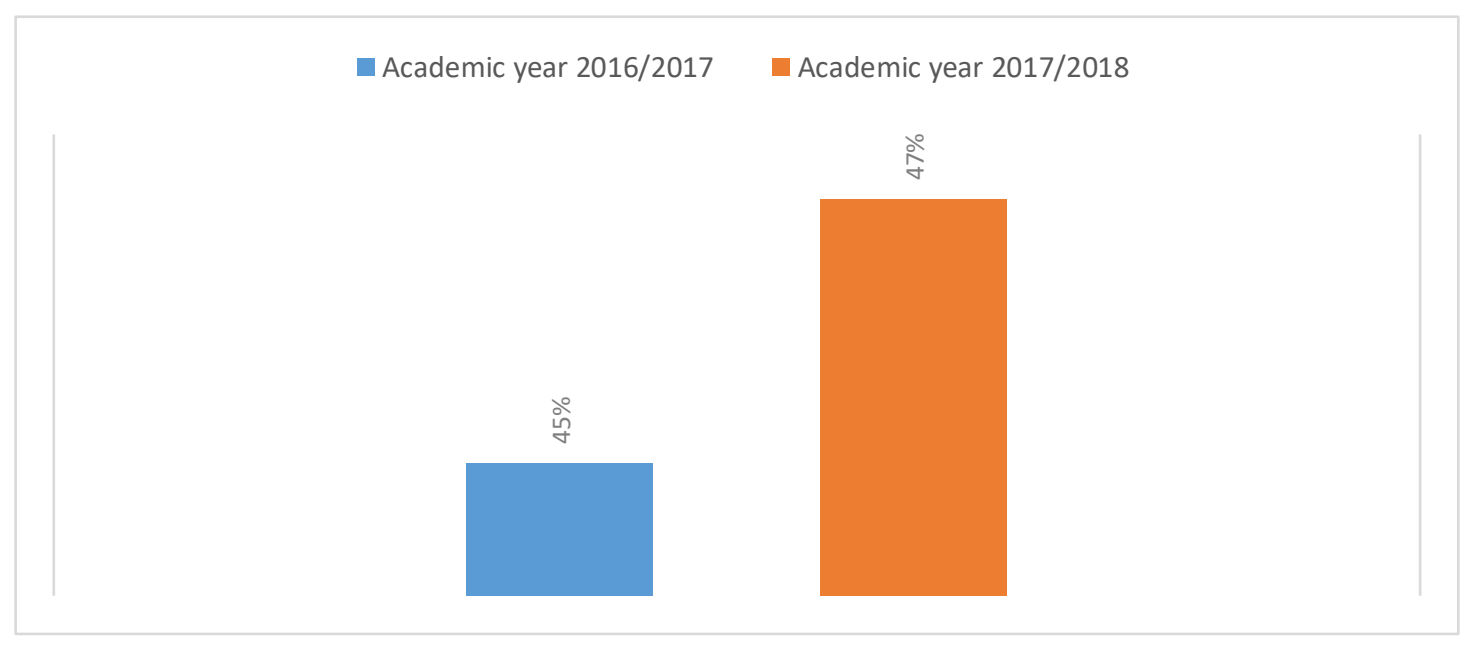

Figure 1. Midterm Exam Result

Based on the recapitulation of the Midterm Examination scores of $6^{\text {th }}$-semester students in the academic year 2016/2017 and 2017/2018, it was found that students who answered correctly on the problem of the volume of the solid of revolution did not reach $50 \%$. This shows 
that most of the Mathematics Education students had difficulty in those subject material.

Regard to mathematics learning difficulties, the results of other studies show that error students are to determine the upper and lower limits of integration (Wahyuni, Kurniawan, Waluya, \& Cahyono, 2019), not yet mastered the substitution integral \& partial integrals (Nursyahidah \& Albab, 2017), have not been able to distinguish the concept of definite integral $\&$ indefinite integral, calculation errors in determining the value of sigma (Rahimah, 2012), errors in applying the methods, errors in determining the right function, careless in multiplying positive and negative numbers, errors in squaring a function, difficulty in representing the image (Rimo, 2018), unable to determine the basic formula of the volume of the solid of revolution, errors in determining the points (abscissa and ordinate), and inaccuracy in operating algebra (Ahmad, 2019).

It is important to know those student errors, so in the future students will no longer have difficulties in understanding the volume of the solid of revolution material subject. Overcome the difficulties of students can be done by analyzing or identifying student errors in solving the problem of the volume of the solid of revolution. This study aims to analyze the errors of students in solving the problem of the volume of the solid of revolutions in terms of critical thinking aspects. Researchers need to conduct this research because there is no previous research that discusses the analysis of student errors when solving the problem of the volume of the solid of revolution in terms of critical thinking aspects.

\section{METHOD}

This research was conducted in a private university in Yogyakarta and involved 38 students on $6^{\text {th }}$-semester of the Mathematics Education Study Program in the academic year 2018/2019 whose take Integral Calculus courses. All of them are asked to solve problems on determining the volume of the solid of revolution bounded by curves $y=x^{2}+2$ and lines $y=1$ at the integrating limit [0.4] and rotated around the $\mathrm{x}$-axis to be done in 20 minutes. Then, researchers check the student's answers. After checking student answers, researchers count the number of students who answered right, wrong, and those who did not answer. The researchers

focused on the incorrect answer because we want to know the mistakes in determining the volume of the solid of revolution.

After that, researchers analyze all of incorrectly answered by recording all the errors made by students in determining the volume of the solid of revolution. Those student's error 
that has been recorded then analyzed based on aspects of critical thinking. The researchers then calculate the percentage of students' error that have been grouped based on the critical thinking aspects using this formula:

$$
\text { Percentage }(\%)=\frac{E}{T} \times 100 \%
$$

where,

$E$ : the number of student's errors in each type

$T:$ the number of students who make mistakes overall

\section{RESULT AND DISCUSSION}

All of $6^{\text {th }}$-semester students who learn Integral Calculus (as many 38 students) asked to solve one problem of the volume of the solid of revolution to be done in 20 minutes. The problem that needs to be done is presented in Figure 2.

\section{B. Soal}

Tentukan volume benda putar yang dibatasi oleh kurva $y=x^{2}+2$ dan garis $y=1$ pada batas pengintegralan $[0,4]$ dan diputar terhadap sumbu- $x$.

Translation

Problem: determine the volume of the rotating object which is bounded by the curve $y=x^{2}+$ 2 and the line $y=1$ at the integration boundary $[0,4]$ and rotated about the $x$-axis.

Figure 2. The Problem of The Volume of The Solid of Revolution

Test results of 38 students were categorized based on the correct, incorrect, and no answer. Researchers then counting the number of students who answered right, wrong, and those who did not answer. The number of students who answered right, wrong, and did not answer are presented in Table 2.

Table 2. Percentage of Student Answers

\begin{tabular}{lc}
\hline Category & The number of students in each category \\
\hline Correct & 12 \\
Incorrect & 24 \\
No answer & 2 \\
\hline
\end{tabular}

Based on Table 2 it is known that there were 24 students who answered incorrectly. It indicates that there are still many students who have difficulty in understanding the subject material. 
After that, researchers analyze all of incorrect answered based on the aspects of critical thinking. Researchers provide examples of analyzing incorrect answered of 3 research subjects. The mistakes of research subjects can be seen in the picture that has been marked with a red box.

\section{Research Subject 1 (S1)}

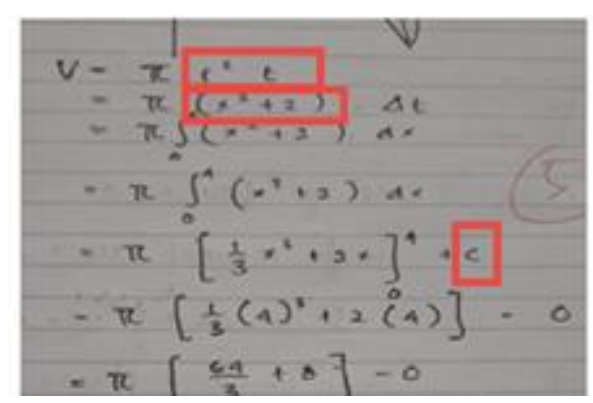

Figure 3. Errors by Subject 1

From figure 3, it can be seen that Subject 1 (S1) has identified the concept used to solve the problem. S1 identifies the concept of volume of the solid of revolution from the tube volume (S1 uses the tube volume approach). The process of identifying concepts in making a decision is based on the similarity between the shape of the tube and the solid of revolution. Students who are able to identify problems and provide the correct and concise answers are students with high levels of problem-solving (Perbowo, Hadi, \& Haryati, 2020).

It's actually true to use the volume of the tube to get the volume of the solid of revolution, but you have to know the shape of the solid of revolution formed. If the slice of the solid of revolution forms a plate, the volume of the solid of revolution can be analyzed using the disc method, where:

$$
\Delta V \approx \pi r^{2} \Delta x
$$

Whereas if the slice of the solid of revolution forms a ring, it can be calculated using the ring method, where:

$$
\Delta V \approx \pi\left[r_{2}^{2}-r_{1}^{2}\right] \Delta x
$$

Equations (1) and (2) are rotary volume equations that resemble the tube volume equations, namely:

$$
V=\pi r^{2} t
$$

S1 seems unable to reduce the volume of the solid of revolution from the volume of the tube, which means that $\mathrm{S} 1$ has been able to identify the concepts that used in making decision but has not re-evaluated the a decision that has been taken whether it is appropriate to calculate 
the volume of the solid of revolution when calculating it with $\pi\left(x^{2}+2\right) \Delta t$. The formula for the volume of the solid of revolution should be written $\pi\left(r_{1}^{2}-r_{2}^{2}\right) \Delta x$. As a consequence, S1 make a mistake in determining the function which should be integrated of $\pi\left(\left(x^{2}+2\right)^{2}-(1)^{2}\right) \Delta x$. In addition, S1 unable to compare another concept, namely the concepts of definite integrals and indefinite integrals. It can be seen from the addition of constants $C$ in the answers given. It is a definite integral problem that did not need to add constants $C$.

2. Research Subject 2 (S2)

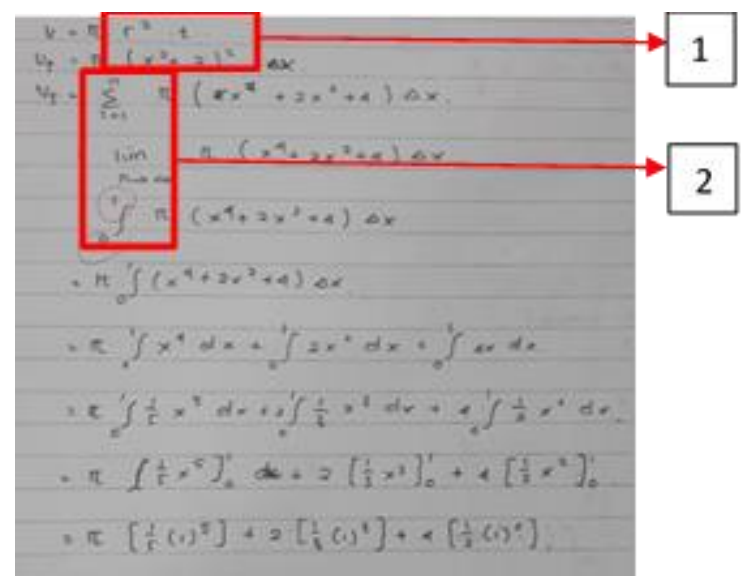

Figure 4. Errors by Subject 2

In solving the problem, Subject 2 (S2) identified the concept of the volume of the solid of revolution also using the concept of a tube volume as seen in figure 4. S2 uses the tube volume approach to solve the problem. The results of this identification are used in making a decision so S2 determines the volume of the solid of revolution using the formula:

$$
\begin{aligned}
& V=\pi r^{2} t \\
& V p=\pi\left(x^{2}+2\right)^{2} \Delta x
\end{aligned}
$$

Based on the test results it can be seen that S2 has not evaluated the steps taken whether the volume of the solid of revolution is integrated by the ring method or disc method. The volume of the solid of revolution should be integrated using the ring method where:

$$
\begin{aligned}
& \Delta V \approx \pi\left[r_{2}^{2}-r_{1}^{2}\right] \Delta x \\
& V p=\pi\left(r_{1}^{2}-r_{2}^{2}\right) \Delta x \\
& V p=\pi\left(\left(x^{2}+2\right)^{2}-(1)^{2}\right) \Delta x
\end{aligned}
$$


In addition, S2 did not look back at the integration limits that requested in the problem. The integrating boundary that corresponds to the problem is $[0,4]$, but S2 integrates it at the boundary $[0,1]$.

Another error made by S2 was an error in write down the rules of integral writing (Figure 2 No. 2). The correct integral writing sequence is:

$$
\begin{aligned}
V_{f} & =\sum_{i=1}^{n} \pi \ldots \ldots \ldots \Delta x \\
V_{f} & =\lim _{n \rightarrow \infty} \sum_{i=1}^{n} \pi \ldots \ldots \ldots . . \Delta x \\
V_{f} & =\int_{0}^{1} \pi \ldots \ldots \ldots \ldots d x
\end{aligned}
$$

But, S2 writes:

$$
\begin{aligned}
V_{f} & =\sum_{i=1}^{n} \pi \ldots \ldots \ldots \Delta x \\
V_{f} & =\lim _{n \rightarrow \infty} \pi \ldots \ldots \ldots . . \Delta x \\
V_{f} & =\int_{0}^{1} \pi \ldots \ldots \ldots . . \Delta x
\end{aligned}
$$

In this case, S2 was unable to identify the characteristics of the concept. S2 was unable to identify how the process of forming integrals. In this section, S2 also unable to compare and apply the concept of limits and sigma notation to subject material that has been studied previously. S2 also did not evaluate the answers written. This can be seen from the writing still in the step that has an integral sign.

$$
\begin{aligned}
& V_{f}=\int_{0}^{1} \pi \ldots \ldots \ldots . . \Delta x \\
& V_{f}=\pi \int_{0}^{1} \ldots \ldots . \Delta x \\
& V_{f}=\pi \int_{0}^{1} \ldots \ldots . d x+\int_{0}^{1} \ldots \ldots . d x
\end{aligned}
$$

This occurs in the initial steps after the existence of the integral sign in step 5 and step 6 , but in step 7 already written $d x$. 
3. Research Subject 3 (S3)

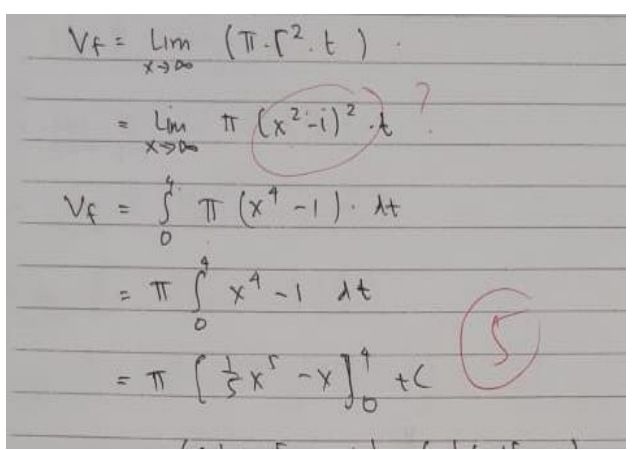

Figure 5. Errors by Subject 3

Based on figure 5, Subject 3 (S3) also identified the concept of the solid of revolution volume using the tube volume approach. In the problem, there was a concept of algebra that must be understood by students namely $V_{f}=\pi\left(r_{1}^{2}-r_{2}^{2}\right) \Delta x$, it means that each radius should be squared first and then subtracted. But what S3 did is subtract first and then squaring the results.

S3 also had unable to identify the characteristics of the integral concept where the integral sign can appear after the sigma and limit notation, in other words, can be written in:

$$
\begin{aligned}
V_{f} & =\sum_{i=1}^{n} \pi \ldots \ldots \ldots \Delta x \\
V_{f} & =\lim _{n \rightarrow \infty} \sum_{i=1}^{n} \pi \ldots \ldots \ldots . . . \Delta x \\
V_{f} & =\int_{0}^{1} \pi \ldots \ldots \ldots . . d x
\end{aligned}
$$

S3 also did not evaluate what he had done. It can be seen from the error in writing the radius of the solid of revolution $(r)$. The things that requested in the problem was to determine the volume of the solid of revolution bounded by curves $y=x^{2}+2$ and lines $y=1$, but S3 wrote $r=x^{2}-1$. S3 basically understood that the problem was solved by the ring method that there was a reduction in the radius. S3 did not understand the concept of algebra. The process of evaluating (re-checking) the answers can be done from the stage of identifying the concept of solving the problem (Irfan, 2018). It can be seen on the test results that S3 adds constants $C$ even though the problem given is a definite integral problem that there are no constants $C$. S3 had unable to compare another concept, namely the concept of a definite integral and indefinite integral.

Then, researchers recording all the errors made by students in determining the volume of the solid of revolution. Those student's error that has been recorded then analyzed based on 
aspects of critical thinking. The types of student's error based on critical thinking aspects were: 1) Identify the characteristics of the concept, namely: misrepresents formed the solid of revolution, misunderstand in algebraic concepts, and write down the rules of integral writing; 2) Compare another concept, namely: adding constants $C$, and write down the limits and sigma notation; 3) Identify the concept that used in making a decision, namely: determine the integration methods; 4) Evaluate the decisions that have been taken, namely: determine the function to be integrated, determine boundaries integration, write down $\Delta x$ in the integral sign, and determine the radius of the solid of revolution.

The next step is researchers calculate the percentage of error for each type. For example the number of students who make mistake in represents formed of the solid of revolution as many as 15 students. Meanwhile, the numbers of students who answered incorrectly in determining the volume of the solid of revolution as many as 24 students, so the percentage of error in represents formed the solid of revolution is $\frac{15}{24} \times 100 \%=62,5 \%$. The percentage of student errors in term of critical thinking are presented in Table 3.

Table 3. Percentage of Students Error in Term of Critical Thinking Aspect

\begin{tabular}{llc}
\hline Indicators of Critical Thinking Ability & \multicolumn{1}{c}{ Students Error } & Percentage of Error (\%) \\
\hline Identify the characteristics of the concept & Misrepresents formed the solid of revolution & 62,5 \\
& Misunderstand in algebraic concepts & 20,8 \\
& Write down the rules of integral writing & 25 \\
Compare another concept & Adding constants $C$ & 37,5 \\
& Write down the limits and sigma notation & 29,2 \\
Identify the concept that used in making a & Determine the integration methods & 58,3 \\
decision & & 54,2 \\
Evaluate the decisions that have been taken & Determine the function to be integrated & 33,4 \\
& Determine boundaries integration & 41,7 \\
& Write down $\Delta x$ in the integral sign & 45,8 \\
\hline
\end{tabular}

It can be concluded that the most mistakes made by students are in drawing the solid of revolution formed, it means that there are still many students who cannot draw the solid of revolutions as requested in the problem. Another error that has the highest percentage is to use an inaccurate integration method and determine the right function to be integrated. The three highest percentage errors are related to each other. If a student is still wrong in drawing the solid of revolution, it will be making a mistake in determining the methods and functions to be integrated.

The findings of this study were in line with the earlier research in which students also have difficulties in solving the problem of the volume of the solid of revolution. The difficulties 
types are understanding the concept, calculation accuracy, and drawing representations. In understanding the concept, students had difficulty in applying the methods, to determine the upper and lower limits of integration, and to determine the right function to be integrated. In the calculation accuracy, students did multiply positive and negative numbers carelessly, and inaccurate in squaring a function. In the representation of images, students were difficult to describe the area bounded by the curve given to the problem (Rimo, 2018). Other studies describe the students' error in calculating the area and the volume of the solid of revolution using a definite integral, namely errors in drawing a parabolic graph and lines, operating algebraic shapes, and determining the volume of the solid of revolution rotating $360^{\circ}$ against the $\mathrm{x}$-axis (Salmina, 2017). Other mistakes made by students in solving integral problems were in determining the upper and lower limits, did not understand the integration technique, and only remembering the formula without understanding its meaning (Wahyuni et al., 2019). Student mistakes can be used as a guide to determine the extent to which students understand the subject material that has been given.

\section{CONCLUSION}

Based on this research, it can be concluded that in term of critical thinking skills, students made mistakes in determining the formulation of the volume of the solid of revolution, write down the rules of integral writing, in understand algebraic concepts, adding constants $C$, write down limits and sigma notation, determine integration methods, determine boundaries integration, write down $\Delta x$ in the steps that had an integral sign, and errors in determining the radius of the solid of revolution. This study allows further research on the factors that cause errors in solving the volume of the solid of revolution problem, what any abilities that are needed besides critical thinking skills, and how the role of the lecturer in reducing student errors in solving the volume of the solid of revolution problem.

\section{REFERENCES}

Ahmad, A. M. (2019). Analisis Kesulitan Belajar Matematika pada Materi Integral Luas Daerah di Bawah Kurva dan Volume Benda Putar. An-Nahdhah, 12(1), 159-176.

Amir, M. F. (2015). Proses berpikir kritis siswa sekolah dasar dalam memecahkan masalah berbentuk soal cerita matematika berdasarkan gaya belajar. JURNAL MATH 
EDUCATOR NUSANTARA: Wahana Publikasi Karya Tulis Ilmiah Di Bidang Pendidikan Matematika, 1(2).

Anggo, M. (2011). Pelibatan metakognisi dalam pemecahan masalah matematika. Edumatica: Jurnal Pendidikan Matematika.

Arigiyati, T. A., \& Istiqomah. (2016). Perbedaan Kemampuan Pemecahan Masalah dengan Pembelajaran Learning Cycle dan Konvensional pada Mahasiswa Prodi Pendidikan Matematika FKIP UST. UNION: Jurnal Ilmiah Pendidikan Matematika, 4(1).

Effendi, L. A. (2012). Pembelajaran matematika dengan metode penemuan terbimbing untuk meningkatkan kemampuan representasi dan pemecahan masalah matematis siswa SMP. Jurnal Penelitian Pendidikan, 13(2), 1-10.

Haryani, D. (2011). Pembelajaran matematika dengan pemecahan masalah untuk menumbuhkembangkan kemampuan berpikir kritis siswa. Prosiding Seminar Nasional Penelitian, Pendidikan Dan Penerapan MIPA, Fakultas MIPA, Universitas Negeri Yogyakarta, Vol. 14.

Irfan, M. (2017). Analisis Kesalahan Siswa dalam Pemecahan Masalah Berdasarkan Kecemasan Belajar Matematika. Kreano, Jurnal Matematika Kreatif-Inovatif, 8(2), 143-14.

Mayer, R. E., \& Wittrock, M. C. (1996). Problem-solving transfer. In Handbook of Educational Psychology (pp. 47-62).

Nursyahidah, F., \& Albab, I. U. (2017). Investigating student difficulties on integral calculus based on critical thinking aspects. Jurnal Riset Pendidikan Matematika, 4(2), 211-218.

Pardimin, P., \& Widodo, S. A. (2016). Increasing Skills of Student in Junior High School to Problem Solving in Geometry with Guided. Journal of Education and Learning, 10(4), $390-395$.

Perbowo, K. S., Hadi, W., \& Haryati, T. (2020). Profile of Mathematical Communication's Ability Based on Level of Problem Solving's Ability. Sigma, 5(2), 65-69. 
Rahimah, D. (2012). Identifikasi Kesalahan Mahasiswa dalam Menyelesaikan Soal-Soal Pokok Bahasan Integral pada Matakuliah Kalkulus Integral. EXACTA, 10(1), 89-97.

Rimo, I. H. E. (2018). Analisis Kesulitan Mahasiswa Pendidikan Fisika FKIP-UNDANA Dalam Memahami Materi Volume Benda Putar. Jurnal Ilmiah Soulmath: Jurnal Edukasi Pendidikan Matematika, 6(2), 91. https://doi.org/10.25139/smj.v6i2.1155

Salmina, M. (2017). Analisis Kekeliruan dalam Menyelesaikan Soal Kalkulus pada Mahasiswa Pendidikan Matematika. Numeracy Journal, 4(2), 62-70.

Santoso, H. (2009). Pengaruh penggunaan laboratorium riil dan laboratorium virtual pada pembelajaran Fisika ditinjau dari kemampuan berpikir kritis siswa. In Doctoral dissertation, UNS (Sebelas Maret University).

Tambychik, T., \& Meerah, T. S. M. (2010). Students' Difficulties in Mathematics ProblemSolving: What do they Say? Procedia-Social and Behavioral Sciences, 8, 142-151.

Wahyuni, A., Kurniawan, P., Waluya, S. B., \& Cahyono, A. N. (2019). Analisis Kesalahan Mahasiswa dalam Menyelesaikan Soal Integral. EDUSAINTEK, 3.

Widjajanti, D. B. (2009). Kemampuan pemecahan masalah matematis mahasiswa calon guru matematika: apa dan bagaimana mengembangkannya. In Seminar Nasional Matematika Dan Pendidikan Matematika, Vol. 5.

Widodo, S. A. (2013). Analisis kesalahan dalam pemecahan masalah divergensi tipe membuktikan pada mahasiswa matematika. Jurnal Pendidikan Dan Pengajaran, 46.

Widodo, S. A., Darhim, \& Ikhwanudin, T. (2018). Improving Mathematical Problem Solving Skills Through Visual Media. JPhCS, 948(1), 012004.

Widodo, S. A., Purnami, A. S., \& Prahmana, R. C. I. (2017). Team Accelerated Instruction, Initials, and Problem-Solves Ability in Junior High School. International Journal on Emerging Mathematics Education (IJEME), 1(2), 193-204. 
132 KALAMATIKA, Volume 5, No. 2, November 2020, pages 119-132

Widodo, S. A., \& Sujadi, A. A. (2015). Analisis Kesalahan Mahasiswa dalam Memecahkan Masalah Trigonometri. SOSIOHUMANIORA: Jurnal Ilmiah Ilmu Sosial Dan Humaniora, 1(1).

Widodo, S. A., \& Turmudi, T. (2017). Guardian Student Thinking Process in Resolving Issues Divergence. Journal of Education and Learning, 11(4), 432-438.

Widodo, S. A., Turmudi, T., Dahlan, J. A., Istiqomah, I., \& Saputro, H. (2018). Mathematical Comic Media for Problem Solving Skills. Proceedings of the Joint Workshop KO2PI and the 1st International Conference on Advance \& Scientific Innovation, 101-108. 